\title{
Pattern and process in MAEUL, a traditional Korean rural landscape
}

\author{
Jae-Eun Kim and Sun-Kee Hong* \\ Institution for Marine and Island Cultures, Mokpo National University, Muan 534-729, Korea
}

\begin{abstract}
Land-use changes due to the socio-economic environment influence landscape patterns and processes, which affect habitats and biodiversity. This study considers the effects of such land-use changes, particularly on the traditional rural "Maeul" forested landscape, by analyzing landscape structure and vegetation changes. Three study areas were examined that have seen their populations decrease and age over the last few decades. Five types of plant life-forms (Raunkier life-forms) were distinguished to investigate ecosystem function. Principle component analysis was used to understand vegetation dynamics and community characteristics based on a vegetation similarity index. Ordination analysis transformed species-coverage data was introduced to clarify vegetation dynamics. Landscape indices, such as area metrics, edge metrics, and shape metrics, showed that spatial heterogeneity has increased over time in all areas. Pinus densiflora was the main land-use plant type in all study areas but decreased over time, whereas Quercus spp. increased. Over a decade, P. densiflora communities shifted to deciduous oak and plantation. These findings indicate that the impact of human activities on the Maeul landscape is twofold. While forestry activities caused heavy disturbances, the abandonment of traditional human activities has led to natural succession. Furthermore, it can be concluded that the type and intensity of these human impacts on landscape heterogeneity relate differently to vegetation succession. This reflects the cause and consequence of patch dynamics. We discuss an approach for sustainable landscape planning and management of the Maeul landscape based on traditional management.
\end{abstract}

Key words: land use, landscape ecology, Maeul, rural landscape, vegetation dynamics

\section{INTRODUCTION}

Landscape change is one of the main driving forces of global environmental change and strongly impacts the world's environmental and landscape attributes (Baker 1995). Rural landscape ecosystems are established through a reciprocal relationship between nature and human impacts (Kamada and Nakagoshi 1996, Hong 1998, 2007, Golley and Bellot 1999, Berkes et al. 2000, Kim et al. 2006). Rural landscapes have been influenced by increasing demands for agricultural productivity and efficiency, which caused humans to begin using chemical fertilizers, pesticides, and herbicides, and finally led to changes in agro-forest management strategies (Hietala-Koivu 1999, Fukamachi et al. 2001, Nakagoshi and Hong 2001). Therefore, changes in socio-economic environments affect rural landscape ecosystems and, particularly, secondary vegetation in agro-forests (Hong 1998, van Lier 1998, Pinto-Correia 2000, Nakagoshi and Hong 2001, Croissant 2004, Woodhouse et al. 2005).

The traditional Korean rural landscape known as "Maeul" is an ecosystem composed of high mountains, easy slopes with low mountains, human settlements, plains with agricultural fields, and streams (Lee 2004,

\section{Open Access DOI: 10.5141/JEFB.2011.025}

This is an Open Access article distributed under the terms of the Creative Commons Attribution Non-Commercial License (http://creativecommons. org/licenses/by-nc/3.0/) which permits unrestricted non-commercial use distribution, and reproduction in any medium, provided the original work is properly cited.
Received 30 March 2011, Accepted 11 April 2011

*Corresponding Author

E-mail: landskhong@gmail.com,skhong@mokpo.ac.kr Tel: +82-61-450-6272 
Kim et al. 2006, 2007, Hong 2007). The term Maeul means village with forest and stream, reflecting the concept that villages in this traditional rural landscape are united with surrounding forests and streams. Traditional Maeul landscapes mainly consist of Pinus densiflora and Quercus spp., particularly in lowland areas near houses and paddy fields, where they are influenced by human impacts (Kamada and Nakagoshi 1993, Hong 1998, Nakagoshi and Hong 2001). Over the long-term, Maeul landscape forests have been used as a source of timber, fuel, and fertilizer for daily human life. Human activities such as thinning and littering control the intensity of sunlight, soil moisture, and temperature. As such, human activities have affected Maeul ecosystems in terms of flora and fauna, causing changes not only at the habitat level but also at the gene level (Burel and Baudry 1995, Jeanneret et al. 2003, Washitani 2003). In other words, human-induced changes in rural landscapes result in habitat changes and affect biodiversity in rural landscape ecosystems (Burel and Baudry 1995, Forman 1995, Turner et al. 1996, Jeanneret et al. 2003). Therefore, studying changes in the Maeul landscape is very important for reasons of natural resources, biodiversity, and culture.

The Korean government established a national landdevelopment program to economically boost rural areas. While this program includes introducing ecotourism and industrial infrastructure into rural areas, it ignores the value that traditional management practices could have to sustain and revive the Maeul landscape. As a result, many of the various ecological functions and integrity in Maeul landscapes are rapidly disappearing.

The management of rural landscapes, such as Korean Maeul landscapes, must include multiple aspects, from both economic and ecological perspectives, to support future landscape planning and management. Researchers can provide the government and farmers with useful information about ecological issues as well as promote sustainable human activities (Hong 2007, Kim et al. 2007). Additionally, long-term ecological studies are necessary to support ecosystem management.

This study considers the effects of land-use changes due to changing socio-economic environments in the Maeul landscape of Korea, because limited information is available on spatial patterns and vegetation structure. We analyzed landscape structures, spatial patterns, and vegetation changes. This study contributes to explaining the relationship between land-use change and forest ecosystems in rural landscapes, which will support the formulation of a basic theory for the planning and sustainable management of these landscapes.

\section{MATERIALS AND METHODS}

\section{Study areas}

Three sites, Teokdong-ri (TD), Teokseong-ri (TS), and Yanghwa-ri (YH), were selected as typical examples of rural landscapes in Korea (Fig. 1). "Ri" is the smallest ad-

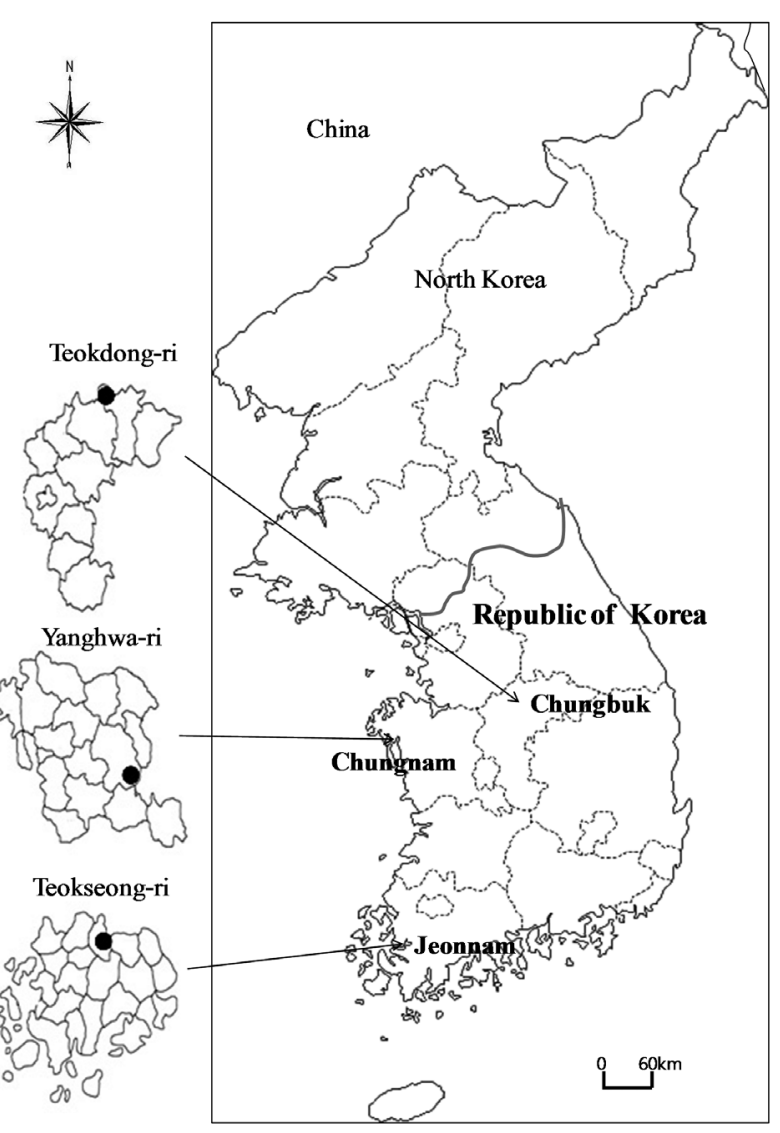

Fig. 1. Map showing the study areas.

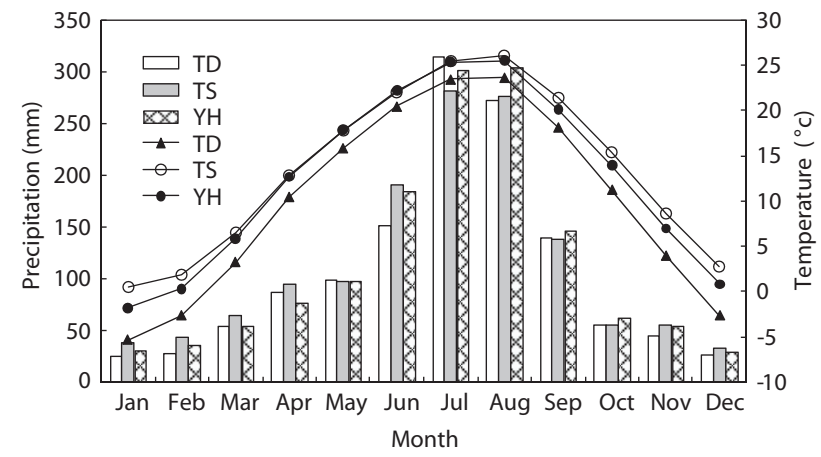

Fig. 2. Mean temperature and mean annual precipitation in the three study areas. TD, Teokdong-ri; Ts, Teokseong-ri; YH, Yanghwa-ri. 

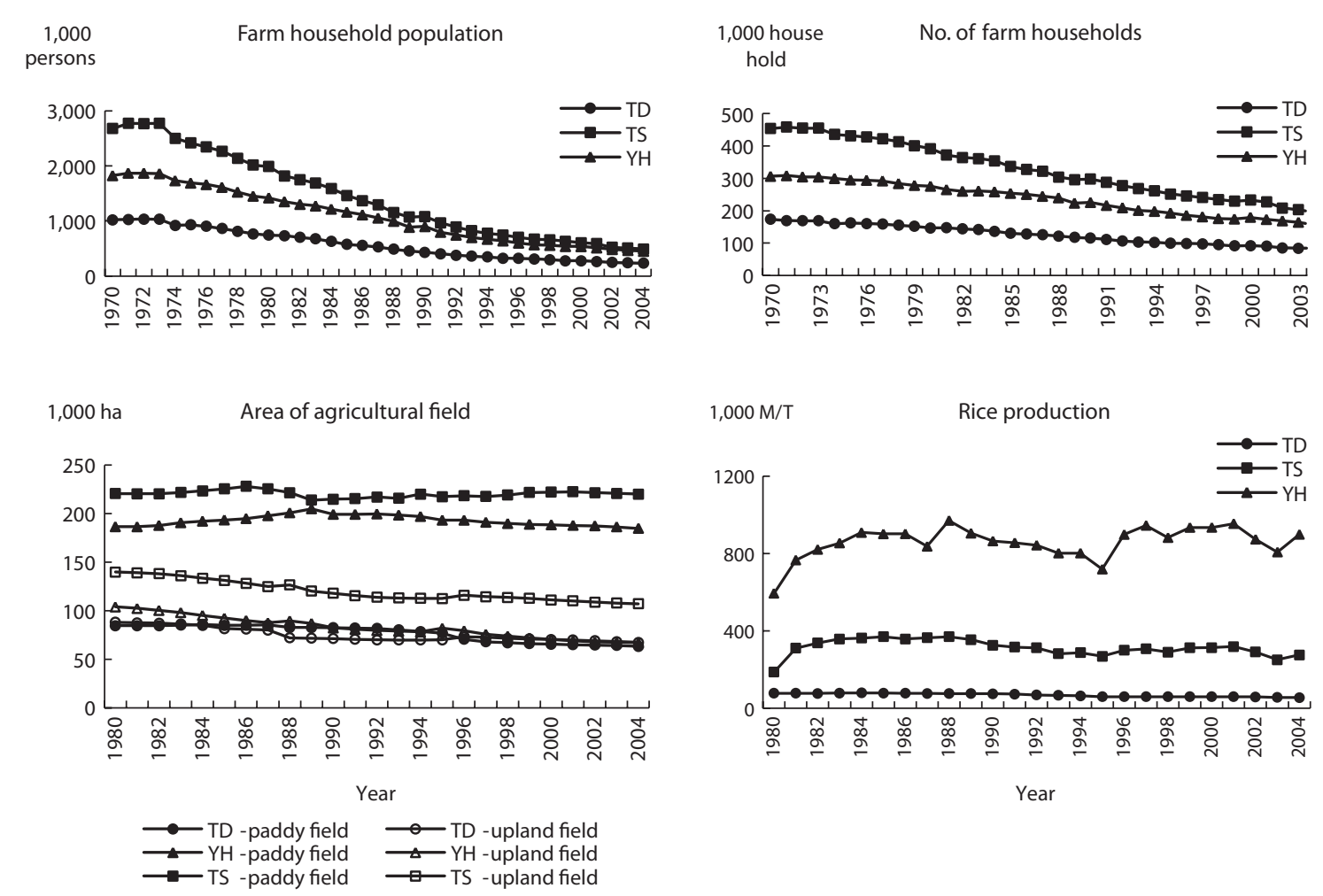

Fig. 3. Trends in the socio-economic environment of the three study areas. Source: Korea Statistical Information System (http://kosis.nso.go.kr/). TD, Teokdong-ri; Ts, Teokseong-ri; $\mathrm{YH}$, Yanghwa-ri.

ministrative district unit in rural areas.

These three study areas belong to temperate midlatitudinal zones (Shin 2002). The climate on the Korean peninsula is characterized by cold dry winters and hot humid summers. The mean monthly precipitation is concentrated during the summer, from June to August, which accounts for almost half of the annual precipitation (Fig. 2). During the dry winter season, from December to February, the mean minimum temperature at TD and $\mathrm{YH}$ is $<0^{\circ} \mathrm{C}$. Regarding potential vegetation, all three areas are located in a deciduous broad-leaved forest zone and covered mainly by Pinus densiflora, Quercus mongolica, and P. densiflora-Quercus spp. mixed communities (Beon and Bartsch 2003, Choung and Hong 2006).

\section{Socio-economic environments}

As stated, the socio-economic environment is one of the main driving forces for landscape change and is very important for managing Maeul landscapes. Hence, socio-economic data were obtained for all three study areas. National statistics related to agricultural systems, farm household populations (Fig. 3), and forest products (Fig. 4) were used as background statistical data to understand the socio-economic environment of Maeul landscapes.

\section{Landscape pattern analysis: mapping and spa- tial indices}

Landscape ecology research is usually based on interpreting aerial photographs and field survey maps (Turner et al. 1996, 2001). Landscape mapping was performed two times for each area, involving the years 1988 and 2002 for TD and TS and 1992 and 2003 for YH.

Land-use types were divided into natural, introduced, and mixed types, according to the original status of the land. The natural type included secondary vegetation or land use due to natural regeneration, although landscape management may have been employed later. P. densiflora forest, Quercus spp. forest, and other secondary forests are included in this type. The introduced type includes vegetation and landscape originally developed by humans for some economic purpose. The mixed type is a combination of both the natural type and the introduced type.

Spatial characteristics (i.e., pattern, diversity, and heterogeneity) of the landscapes were analyzed with FRAG- 
STATS spatial statistics (McGarigal and Marks 1995). In particular, spatial indices (i.e., size, number, and patch density) for each land-use type were adopted to understand the relationship among land-use types in land-
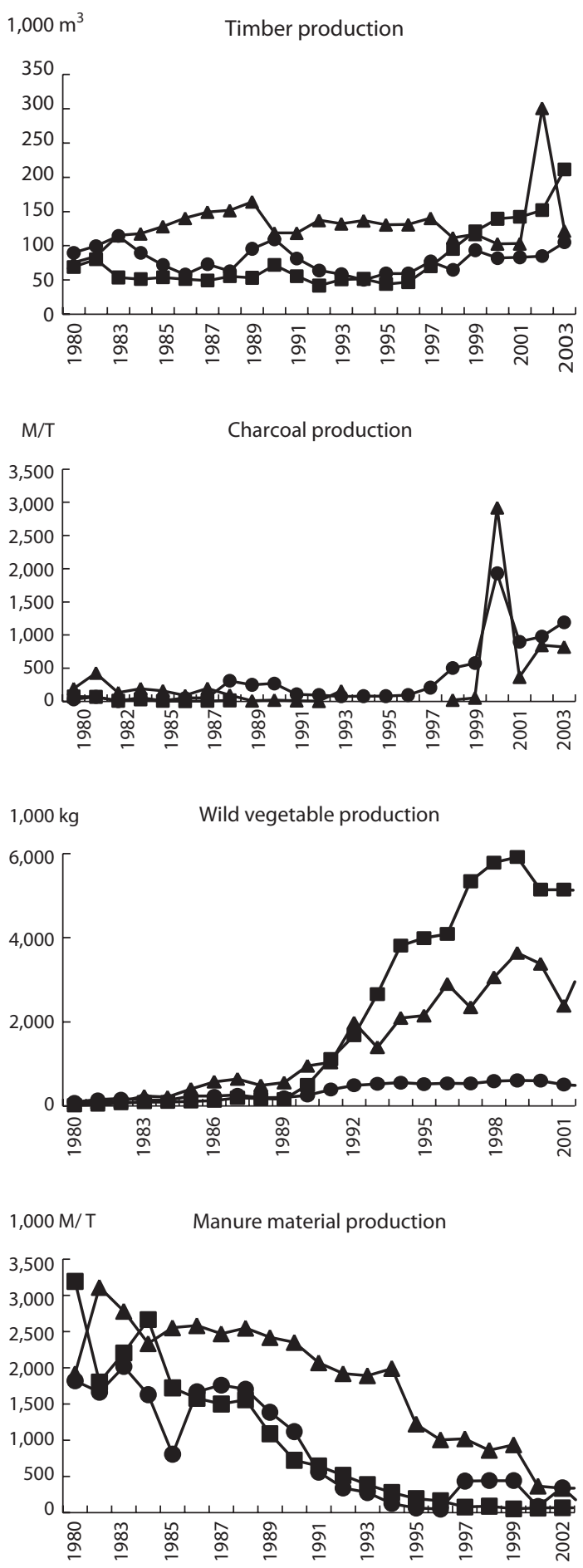

scape mosaics.

Landscape indices were applied to measure spatial patterns (McGarigal and Marks 1995, Hietala-Koivu 1999, Turner et al. 2001). Mean patch size (MPS) was used as
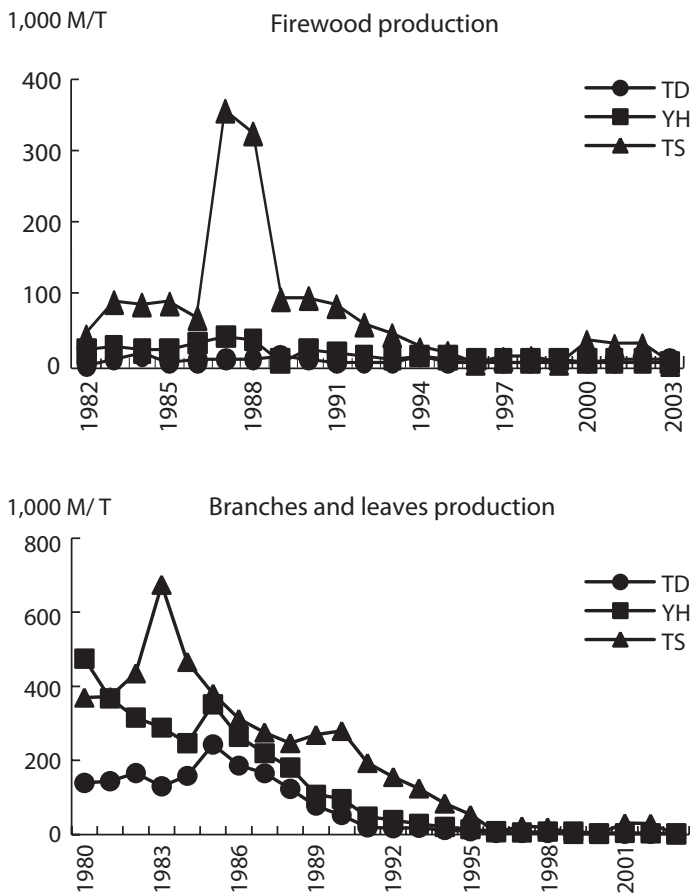

$1,000 \mathrm{M} / \mathrm{T} \quad$ Fuel production

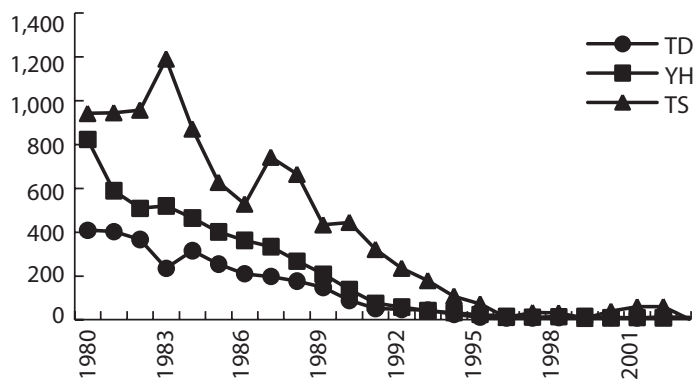

$1,000 \mathrm{M} / \mathrm{T} \quad$ Green manure production

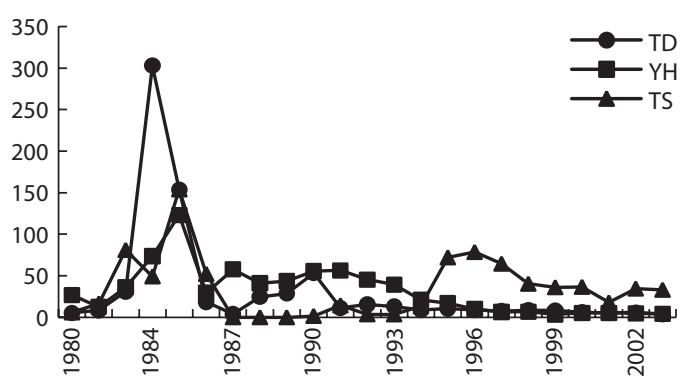

Fig. 4. Trend of changing forest production in the three study areas. Source: Korea Statistical Information System (http://kosis.nso.go.kr/). TD, Teokdong-ri; Ts, Teokseong-ri; YH, Yanghwa-ri. 
a habitat fragmentation index. Mean patch edge (MPE) in edge metrics was used as an habitat indicator, such as habitats for edge species.

Patch shape complexity was measured using the areaweight mean shape index (AWMSI) and the area-weight mean patch fractal dimension (AWMPFD). Both AWMSI and AWMPFD are used to compare changes in the shape of landscape mosaics and to show patch shape by patch area and perimeter. Both indices were used as wildlife habitat indicators when the patch shape was more natural, i.e., has more complicated boundaries as the value increases (Turner et al. 2001, Moser et al. 2002). AWMSI and AWMPFD are more suitable than the mean shape index and the mean patch fractal dimension when only a few land-use types are dominant (McGarigal and Marks 1995), as is the case for the sites studied here.

All land-use types were identified and their number and size were measured by spatial statistics.

\section{Field survey, plant life-form analysis, and veg- etation dynamics}

Field surveys were conducted to assess plant community structure at each study area. These were conducted in August, when the land-use mapping was performed. Permanent quadrat plots $\left(10 \times 10 \mathrm{~m}^{2}\right.$ in tree layers, $5 \times$ $5 \mathrm{~m}^{2}$ in herb layers) were set in 1988 for TD and TS and in 1992 for $\mathrm{YH}$, and the coverage and abundance of each species were measured. The second surveys were carried out in 2002 and 2003 at the same locations as the previous survey. Species names were used according to Lee's (1996) illustrations. All 152 plots and all vascular plants were surveyed by the Braun-Blanquet (1964) method and arranged by table, which is the general approach for analyzing vegetation structure.

Plant life form is an indicator of ecosystem function (Walker and Langridge 2002), so it may explain changing landscape ecosystems through time in rural forests. Raunkiaer's life-form system was introduced to consider the degree of forest development and structure (Nakagoshi et al. 1992). Therefore, life-form data were used as qualitative community data, whereas relative species richness and species diversity were used as quantitative data. Species diversity was measured by the ShannonWiener diversity index (Saïd 2001). Relative species richness and species diversity of each life form explains different ecosystem environments (Saïd 2001).

Communities were defined by homogenous physiognomy and confirmed using the phytosociological procedure (Braun-Blanquet 1964). Each plant commu- nity was identified by identifying the dominant species. Forest structure community characteristics and species composition are simultaneously shown on the land-use map. Morisita's similarity index, $\mathrm{C} \lambda(p)$, which explains the inter-stand similarities (Morisita 1959), was used for this community analysis. This index is calculated based on floristic composition and coverage.

Principle component analysis (PCA), based on the vegetation similarity index, was conducted to understand vegetation dynamics and community characteristics. Moreover, PCA ordination (PC-ORD ver. 4.01; MjM, Gleneden, Beach, OR, USA) was applied to estimate vegetation changes on a spatio-temporal scale. Ordination is a collective term for the multivariate techniques that arrange sites along axes based on species composition data (Jongman et al. 1995). This means that the vegetation arrangements in relation to each other (similarities in species composition and/or their associated environmental gradients) indicate community characteristics in a rural forest.

\section{Statistical analysis}

A regression analysis was conducted to understand the relationships between changing spatial patterns and qualitative communities in the rural forest. Landscape indices were used to indicate landscape structure characteristics, particularly spatial patterns in rural landscapes, and also species diversity, given that each type of plant life form indicates the status of a rural forest ecosystem.

\section{RESULTS}

\section{Landscape structure and socio-economic envi- ronment}

From the mid 1970s, the farm household population and the number of farm households decreased gradually in all three study areas (Fig. 3). The main reason for this is that people moved to surrounding large cities to increase their standard of living. This was most severe at TS, which saw its population decrease by more than half. The farm household population at all three study areas decreased most abruptly from 1970 to 1990. After that, the decreases slowed, because rural regions began to develop ecotourism beginning in 1988 and the speed of economic development across the country slowed.

Forest production showed decreasing trends, except for timber, charcoal, and wild vegetables (Fig. 4). At TD, 
J. Ecol. Field Biol. 34(2): 237-249, 2011

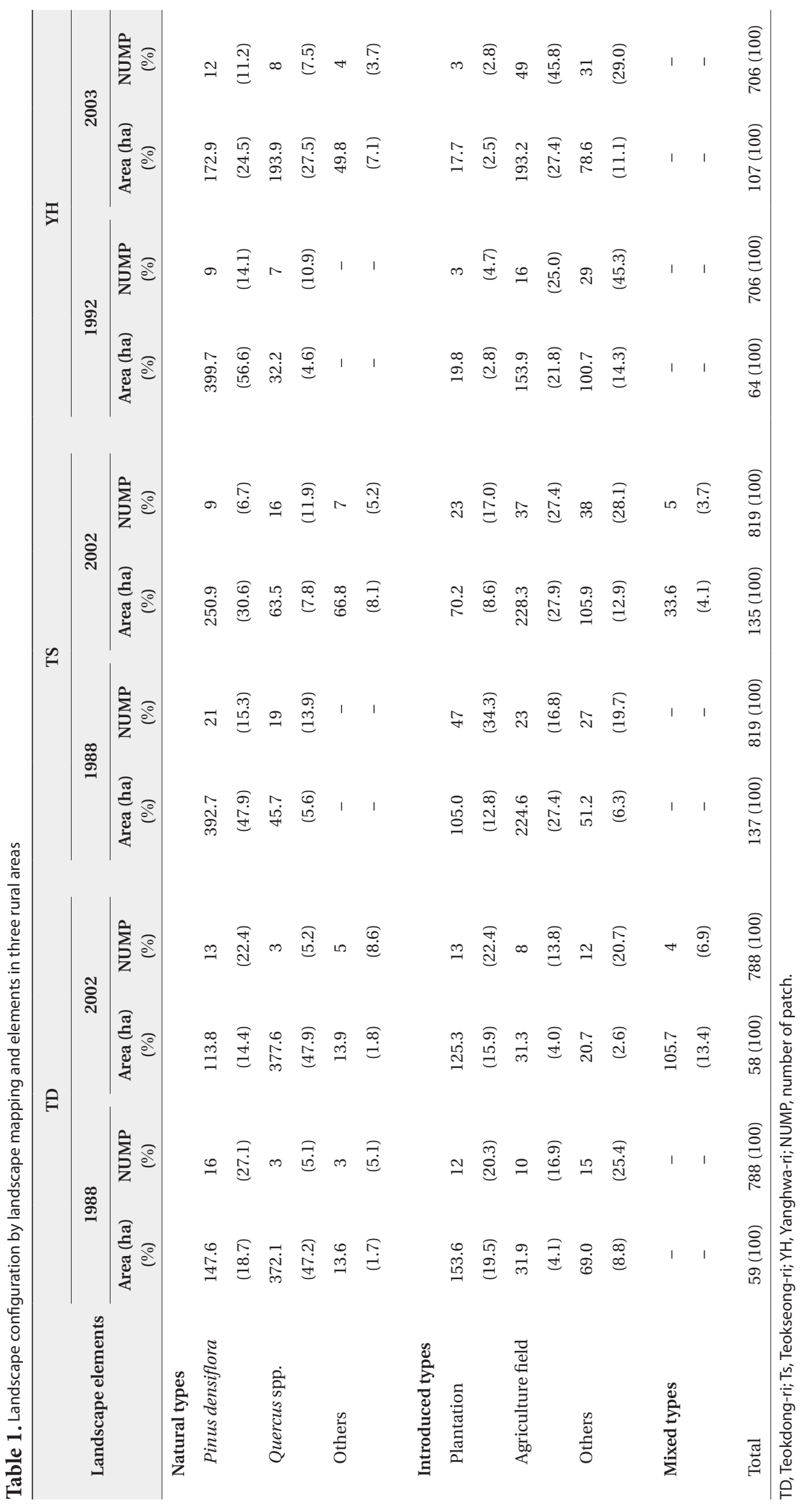

DOI: 10.5141/JEFB.2011.025

242 
the national and public land ownership was nearly $61 \%$ $(6,820 \mathrm{ha})$ of the total forested area $(11,186 \mathrm{ha})$, whereas forestry for timber and fuel production was the main economic activity. In contrast, the other two study areas had mainly privately owned land, with nearly $95 \%(2,291$ ha) of the 2,400 ha of forest at TS and nearly $89 \%(58,867$ ha) of the 65,871 ha of forest at $\mathrm{YH}$.

The area and number of $P$. densiflora patches decreased in all study areas, whereas the area and number of Quercus spp. patches increased in all study areas, particularly at $\mathrm{YH}$ where the increase was from 32.2 ha (4.6\%) to 193.9 ha $(27.5 \%)$ (Table 1$)$. The area of other natural land-use types also increased in all study areas. At TD, this change was a slight increase, whereas at TS and YH it occurred as a new land-use type in 2002 (66.8 ha, 8.1\%) and 2003 (42.0 ha, 5.9\%). The main community compositions at TS and $\mathrm{YH}$ were mixed communities such as $P$. densiflora with Quercus spp.

The area and number of plantation patches decreased at all three study areas. Agricultural field area, including paddy fields and upland fields, decreased slightly at TD from 31.9 ha (4.1\%) to 31.3 ha $(4.0 \%)$, whereas it increased at both TS and YH. Actually, in the latter two cases the paddy field area decreased but upland fields increased to a larger extent from 53 ha $(6.5 \%)$ to 68.4 ha $(8.4 \%)$ at TS and from 9.7 ha $(1.4 \%)$ to 87.7 ha $(12.4 \%)$ at YH. The area of other introduced land-use types decreased at TD and YH, whereas it increased at TS.

The landscape indices MPS, MPE, AWMSI, and AWMPFD were used to analyze spatial patterns. The MPS of $P$. densiflora decreased at TD and YH, whereas it increased at TS (Table 2). The MPS of Quercus spp. increased at all study areas, particularly at $\mathrm{YH}$ where the increase was six-fold. Agricultural fields had decreased MPS at TS and YH, whereas they increased slightly at TD. The MPE for the P. densiflora and Quercus spp. decreased at all study areas. P. densiflora and Quercus spp. patch shape, as measured by AWMSI and AWMPFD, increased at TS and YH but decreased at TD. In other words, the patch shape became more irregular at TS and YH compared with at TD.

Table 2. Configuration of spatial patterns by study area and year

\begin{tabular}{|c|c|c|c|c|c|c|c|c|c|}
\hline Landscape indices & Area & Year & 1 & 2 & 3 & 4 & 5 & 6 & 7 \\
\hline \multirow[t]{6}{*}{ MPS (ha) } & TD & 1998 & 9.2 & 124.0 & 4.5 & 12.8 & 3.2 & 4.6 & - \\
\hline & & 2002 & 8.8 & 125.9 & 2.8 & 9.6 & 3.9 & 1.7 & 26.4 \\
\hline & TS & 1998 & 18.7 & 2.4 & - & 2.2 & 9.8 & 1.9 & - \\
\hline & & 2002 & 27.9 & 4.0 & 9.5 & 3.1 & 6.2 & 2.8 & 6.7 \\
\hline & $\mathrm{YH}$ & 1992 & 44.4 & 4.6 & - & 5.6 & 9.6 & 3.5 & - \\
\hline & & 2003 & 14.4 & 24.2 & 21.0 & 5.9 & 3.9 & 2.5 & 3.9 \\
\hline \multirow[t]{6}{*}{ MPE (m) } & TD & 1998 & $1,572.5$ & $7,431.4$ & $1,946.3$ & $1,932.2$ & 960.8 & $1,151.4$ & - \\
\hline & & 2002 & $1,439.9$ & $7,125.8$ & $1,379.5$ & $1,718.9$ & 956.7 & $1,483.2$ & $3,121.9$ \\
\hline & TS & 1998 & 2,648.5 & 657.1 & - & 730.8 & $2,071.9$ & 998.4 & - \\
\hline & & 2002 & $3,885.6$ & 989.4 & $1,919.4$ & 925.6 & $1,387.6$ & $1,066.6$ & $1,417.2$ \\
\hline & $\mathrm{YH}$ & 1992 & $4,176.6$ & $1,107.2$ & - & $1,646.7$ & $1,859.7$ & $1,094.2$ & - \\
\hline & & 2003 & $3,155.4$ & $2,775.2$ & $3,200.4$ & $1,296.7$ & $1,100.4$ & $1,168.7$ & $1,021.7$ \\
\hline \multirow[t]{6}{*}{ AWMSI } & $\mathrm{TD}$ & 1998 & 2.212 & 2.290 & 3.046 & 2.587 & 2.275 & 1.730 & - \\
\hline & & 2002 & 1.876 & 2.232 & 2.787 & 1.689 & 1.424 & 4.020 & 2.167 \\
\hline & TS & 1998 & 2.660 & 1.369 & - & 1.718 & 3.373 & 3.183 & - \\
\hline & & 2002 & 2.874 & 1.531 & 1.787 & 1.816 & 2.464 & 2.215 & 1.643 \\
\hline & $\mathrm{YH}$ & 1992 & 2.242 & 1.662 & - & 1.893 & 2.153 & 2.269 & - \\
\hline & & 2003 & 2.824 & 2.754 & 2.131 & 1.588 & 1.937 & 4.308 & 1.444 \\
\hline \multirow[t]{6}{*}{ AWMPFD } & TD & 1998 & 1.320 & 1.286 & 1.425 & 1.333 & 1.362 & 1.309 & - \\
\hline & & 2002 & 1.306 & 1.283 & 1.415 & 1.303 & 1.300 & 1.462 & 1.305 \\
\hline & TS & 1998 & 1.335 & 1.300 & - & 1.337 & 1.374 & 1.413 & - \\
\hline & & 2002 & 1.344 & 1.311 & 1.313 & 1.340 & 1.349 & 1.363 & 1.308 \\
\hline & $\mathrm{YH}$ & 1992 & 1.293 & 1.319 & - & 1.339 & 1.333 & 1.329 & - \\
\hline & & 1003 & 1.367 & 1.327 & 1.324 & 1.302 & 1.342 & 1.382 & 1.307 \\
\hline
\end{tabular}

1, Pinus densiflora; 2, Quercus spp.; 3, others in natural types; 4, plantation; 5, agricultural field; 6, others in introduced types; 7, mixed types.

MPS, mean patch size (ha); TD, Teokdong-ri; Ts, Teokseong-ri; YH, Yanghwa-ri; MPE, mean patch edge (m); AWMSI, area-weight mean shape index; AWMPFD, area-weight mean patch fractal dimension. 


\section{Vegetation and plant life forms}

The 424 species identified by the phyto-sociological data were surveyed in 1998 and 2002 for TD and TS and in 1992 and 2003 for YH.

Five types of plant life forms were distinguished: phanerophytes, chamaephytes, hemicryptophytes, geophytes, and therophytes. Fig. 5a shows the relative species richness of these life-form types for each year and study area. The main life-form type in all study areas was phanerophytes ( $>45 \%$ in each year) and hemicryptophytes ( $>25 \%$ in each year). This means that mainly tree species and perennial herb species occurred in all study areas.

The species diversity of the given life-form types is shown in Fig. 5b. Therophyte species diversity increased from 1.375 to 1.404 at YH, whereas it decreased at the two other areas. Chamaephyte diversity increased at TS and YH but not at TD. Hemicryptophytes diversity decreased in all study areas.

Phytosociological data were analyzed by means of PCA ordination using the interstand similarity index of Morisita (1959) to elucidate community characteristics (Fig. 6). The correlation coefficients of the environmental variables on the first two PCA axes (Table 3) indicated that axis 1 (eigenvalue, 0.68) was negatively correlated with herb layer height. Axis 2 (eigenvalue, 0.17) was negatively correlated with sub-tall tree layer height. Based on the scatter pattern, community distribution could be divided into four groups. Group 1 consisted of only P. densiflora communities. Group 2 consisted of mixed communities such as P. densiflora with Quercus spp. and P. densiflora

Table 3. Correlations among environmental variables on the first two principal components analysis axes

\begin{tabular}{lll}
\hline Variables & Axis 1 & Axis 2 \\
\hline Elevation & -0.575 & $-0.744^{* *}$ \\
Slope & -0.514 & $-0.802^{* *}$ \\
Species number & -0.586 & $-0.690^{*}$ \\
Height of tall tree layer & $-0.682^{*}$ & $-0.825^{* *}$ \\
Height of sub-tall tree layer & $-0.692^{*}$ & $-0.874^{* *}$ \\
Height of shrub layer & $-0.787^{* *}$ & $-0.846^{* *}$ \\
Height of herb layer & $-0.794^{* *}$ & $0.689^{*}$ \\
Coverage of tall tree layer & $-0.662^{*}$ & $-0.752^{* *}$ \\
Coverage of sub-tall tree layer & $-0.745^{* *}$ & $-0.667^{* *}$ \\
Coverage of shrub layer & $-0.771^{* *}$ & $-0.734^{* *}$ \\
Coverage of herb layer & $0.728^{* *}$ & $0.729^{* *}$ \\
\hline
\end{tabular}

${ }^{*} P<0.05,{ }^{* *} P<0.01$. with $P$. rigida communities. Group 3 consisted of plantation, graveyard, orchard, and shrub communities at clear
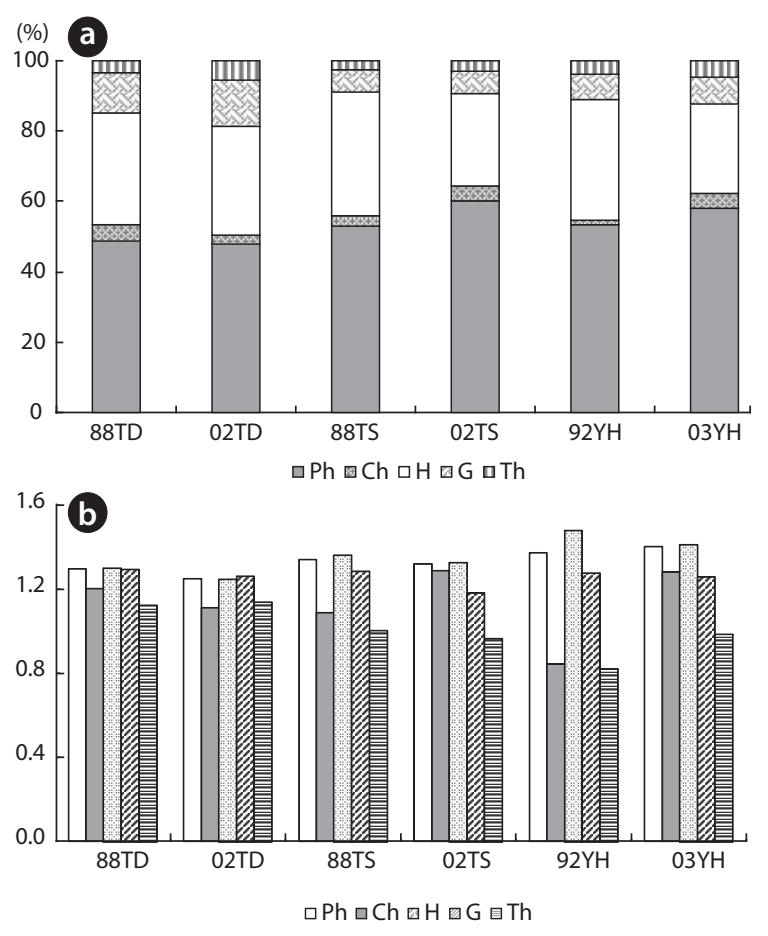

Fig. 5. Relative species richness (a) and species diversity (b) in a given life form by study area and year. TD, Teokdong-ri; Ts, Teokseong-ri; YH, Yanghwa-ri; Ph, phanerophytes; $\mathrm{Ch}$, chamaephytes; $\mathrm{H}$, hemicryptophytes; G, geophytes; Th, therophytes; 88 , the year of $1988 ; 02$, the year of 2002; 92 , the year of 1992; 03, the year of 2003.

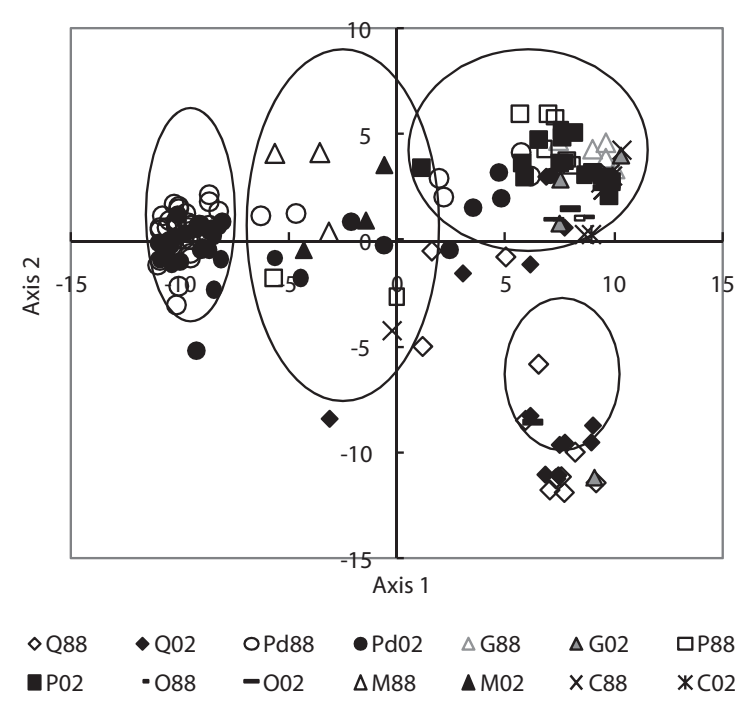

Fig. 6. Position of the study plots in relation to the principal components analysis axes 1 and 2. Axis 1 was negatively correlated with herb layer height and axis 2 was negatively correlated with sub-tall tree layer height. $Q$, deciduous oak; Pd, Pinus densiflora; G, graveyard; P, plantation; O, orchard; M, mixed forest; C, others; 88, the year of 1988; 02, the year of 2002. 
cutting sites, which were strongly disturbed by human activities. Group 4 consisted of mainly Quercus spp. and abandoned orchards and graveyards, particularly at $\mathrm{YH}$. The group 1 arrangement was closest to axis 2. However, groups 3 and 4 were more suitable than group 1 for developing shrub and herb layers. Group 4 was located close to axis 1 and, thus, was suitable for tree layer development.

\section{Relationship between spatial pattern and life form}

The relationship between spatial pattern and species diversity for each life form was examined by regression analysis by interpreting the $r^{2}$ values (Table 4). P. densiflora and Quercus spp. were significantly associated with floristic life forms. The MPS and MPE of therophytes were significantly related to P. densiflora and Quercus spp., indicating that MPS and MPE are influenced by annual herb species. Phanerophytes, hemicryptophytes $(P$ $<0.01)$, and therophytes $(P<0.05)$ showed a significant relationship with $P$. densiflora in AWMSI. Phanerophytes and hemicryptophytes in the AWMPFD were significantly associated with $P$. densiflora and Quercus spp., indicating that tree and perennial species are influenced by patch shape in AWMPFD.

\section{DISCUSSION}

\section{Changing rural landscape and human activities}

The three study areas have undergone significant changes due to depopulation and the effect of an aging population. These trends have been caused mainly by residents moving to surrounding bigger cities to increase their standard of living. The agricultural field area showed a decreasing trend in all study areas, but rice production increased at TS and YH, whereas it decreased only slightly at TD (Fig. 3), indicating a higher degree of agricultural efficiency at TS and YH. The main agriculture type in these areas used to be rice paddy fields, but the proportion of upland fields seemed to increase steadily. This was also influenced by political issues, as the opening agricultural production markets, particularly for rice, has not been highly competitive (Lim and Cho 2004). Hence, changes in the socio-economic environment are leading to changes in the Maeul landscape.

However, trends in forest production such as timber, firewood, charcoal, branches and leaves, fuel, wild vegetables, and manure production illustrate the forest management culture. Due to economic development, forest production has generally decreased because of a

Table 4. Regression analysis between spatial pattern and species diversity for five plant life forms ( $r^{2}$ values)

\begin{tabular}{|c|c|c|c|c|c|c|}
\hline & & Pinus densiflora & Quercus spp. & Plantation & Agriculture field & I-Others \\
\hline \multirow[t]{5}{*}{ MPS } & $\mathrm{Ph}$ & 0.518 & 0.683 & 0.549 & 0.001 & 0.765 \\
\hline & $\mathrm{Ch}$ & 0.804 & 0.149 & 0.049 & 0.263 & 0.038 \\
\hline & $\mathrm{H}$ & 0.779 & 0.737 & 0.550 & 0.668 & 0.668 \\
\hline & $\mathrm{G}$ & 0.036 & 0.382 & 0.479 & 0.060 & 0.060 \\
\hline & Th & $0.876^{*}$ & $0.846^{*}$ & 0.678 & 0.135 & 0.474 \\
\hline \multirow[t]{5}{*}{ MPE } & $\mathrm{Ph}$ & 0.758 & 0.603 & 0.380 & 0.019 & 0.808 \\
\hline & $\mathrm{Ch}$ & 0.059 & 0.182 & 0.289 & 0.212 & 0.224 \\
\hline & $\mathrm{H}$ & 0.749 & 0.687 & 0.319 & 0.123 & 0.673 \\
\hline & G & 0.531 & 0.411 & 0.529 & 0.265 & 0.199 \\
\hline & Th & $0.858^{*}$ & $0.835^{*}$ & 0.442 & 0.119 & 0.545 \\
\hline \multirow[t]{5}{*}{ AWMSI } & $\mathrm{Ph}$ & $0.951^{* *}$ & 0.126 & 0.324 & 0.192 & 0.799 \\
\hline & $\mathrm{Ch}$ & 0.292 & 0.371 & 0.418 & 0.122 & 0.301 \\
\hline & $\mathrm{H}$ & $0.923^{* *}$ & 0.159 & 0.108 & 0.222 & 0.665 \\
\hline & G & 0.074 & 0.328 & 0.529 & 0.075 & 0.217 \\
\hline & Th & $0.851^{*}$ & 0.465 & 0.165 & 0.183 & 0.552 \\
\hline \multirow[t]{5}{*}{ AWMPFD } & $\mathrm{Ph}$ & $0.862^{*}$ & $0.9947^{* *}$ & 0.054 & 0.362 & 0.620 \\
\hline & $\mathrm{Ch}$ & 0.284 & 0.104 & 0.529 & 0.259 & 0.144 \\
\hline & $\mathrm{H}$ & $0.813^{*}$ & $0.878^{*}$ & 0.368 & 0.328 & 0.606 \\
\hline & G & 0.274 & 0.198 & 0.015 & 0.107 & 0.075 \\
\hline & Th & 0.589 & 0.808 & 0.552 & 0.196 & 0.529 \\
\hline
\end{tabular}

${ }^{*} P<0.05,{ }^{* *} P<0.01$.

MPS, mean patch size; Ph, phanerophytes; Ch, chamaephytes; $\mathrm{H}$, hemicryptophytes; $\mathrm{G}$, geophytes; Th, therophytes; MPE, mean patch edge; AWMSI, areaweight mean shape index; AWMPFD, area-weight mean patch fractal dimension. 
fuel revolution and changes in agricultural materials (Kamada and Nakagoshi 1996, Hong 1998, Kim et al. 2006). Only the production of charcoal and wild vegetables has increased. In the case of charcoal production, Korean people enjoy grilling meat with charcoal, particularly that produced from oak trees (Fig. 4) and this has become popular at restaurants. Wild vegetable production increased from the 1990s when people began to adopt habits to improve their health and well-being. Korean people consider wild vegetable consumption good for their health, so as consumption increased production increased. Thus, human cultural impacts have influenced forest production. Moreover, these cultural activities support the rural forest ecosystem and help to control the natural regeneration of habitats.

Maeul landscapes in Korea mainly consist of secondary vegetation such as $P$. densiflora and deciduous oak. In particular, $P$. densiflora in Maeul landscapes has experienced human impacts for some time (Hong 1998, 2007, Kim et al. 2002, 2006, Choung and Hong 2006). Areas of $P$. densiflora forest decreased while Quercus spp. forest increased. $P$. densiflora in Korea has also been influenced by the socio-economic environment (Hong 1998, Kim et al. 2006). The area of Quercus spp. increased more than eight times during the research period and the area of mixed P. densiflora forest also increased. Plantation areas decreased, as the invasion of Quercus spp. into abandoned plantations at TD and TS created mixed forests. Quercus spp. is developing as potential vegetation in Korean rural forest ecosystems without traditional human activities (Hong 1998, Beon and Bartsch 2003, Choung and Hong 2006).

P. densiflora, Quercus spp., and plantations, as main land-use types, are an important driving force affecting spatial patterns in the study areas. Spatial heterogeneity at TD decreased, whereas TS and YH showed increases. In particular, the $P$. densiflora MPS at YH increased compared to that of Quercus spp. and patch shape became more complex. Abandoned P. densiflora patches were invaded by surrounding Quercus spp. patches, which is potential vegetation in these study areas.

\section{Relationship between spatial heterogeneity and vegetation structure}

Five types of flora life forms were distinguished: phaneorphytes, chamaephytes, hemicryptophytes, geocryptophytes, and therophytes. Species diversity decreased for each life form, except for therophytes at TD and chamaephytes at TS (Fig. 5). The annual and biannual plant species habitats at TD may improve. At TS, the habitats may also improve for small shrub species. However, species diversity at $\mathrm{YH}$ increased, except for geocryptophytes and hemicryptophytes. Given the PCA ordination outcome, the increase in tree and small-shrub species diversity may indicate that natural succession occurred at YH. Moreover, fluctuations in species diversity and relative species richness over time might, to some extent, be a response to the complexity of the relationship between the vegetation and the environment.

The scatterplot patterns for the PCA ordination revealed four groups (Fig. 6). Group 1 had two directions; one going to group 3 representing forestry human activities and another was directed towards group 4 , which represented natural succession. Group 2 formed a middle stage in terms of vegetation dynamics. The P. densiflora communities in the three study areas had different vegetation dynamics. TD and TS showed dynamics in response to agro-forestry activities by humans such as plantations, orchards, and graveyards, whereas $\mathrm{YH}$ showed natural succession processes such as the invasion of Quercus spp. into abandoned graveyards and orchards.

The regression analysis between spatial pattern and species diversity showed the relationship between $P$. densiflora and Quercus spp. among land-use types (Table 4). Annual and biannual plant species were significantly associated with MPS and MPE. These plant species may be sensitive to patch size and amount of patch edge, which are important components for edge species (Croissant 2004, Woodhouse et al. 2005). AWMSI and AWMPFD as patch shape indices were associated significantly with tree, perennial herb, biannual herb, and annual herb species in P. densiflora. AWMPFD in Quercus spp. also indicated a significant relationship with tree and perennial herb species. P. densiflora patch shape may influence habitats in tree species and all types of herb layer species. However, patch shape in Quercus spp. may influence tree and perennial herb species. Therefore, $P$. densiflora spatial patterns have more of an influence on habitats of herb species than that of Quercus spp., so P. densiflora may affect herb species diversity and, consequently, biodiversity.

\section{Management strategy for rural forest landscape conservation}

Rural landscapes are usually located between urban areas and mountainous forests. This location provides them a role as an ecotone ecosystem, which can mod- 
erate the human impacts from city areas (Forman 1995). As mentioned, traditional human activities in rural landscapes are interrelated with forest ecosystems. Ruralliving Koreans have traditionally depended on the Maeul landscape for daily life and agriculture (Hong et al. 1995, Hong 1998, Kim et al. 2002). They would cut branches and trees and collect fallen leaves for fuel, timber, and fertilizer. These human activities affect light conditions, soil moisture, and litter depth, and, as such, they control the rural forest ecosystem in a way that is similar to natural regeneration. Therefore, both floral and faunal species can use the Maeul landscape as a habitat (Washitani 2003).

The current Maeul landscape in Korea is confronted by various changes in the socio-economic environment, such as human depopulation, agricultural efficiency, and an aging population, which influence secondary vegetation (Hong 1998, Nakagoshi and Hong 2001, Turner et al. 2001). The deterioration of the Maeul landscape is further accelerated by vegetation dynamics as well as changes in habitat.

Changes in the socio-economic environment, such as industrialization, urbanization, and farm mechanization influence rural landscapes when they lead to a decrease in traditional human activities and a change in land use (van Lier 1998, Oreszczyn 2000, Hong 2001, Takeuchi 2010). Abandoned rural landscapes lose their interrelationship with humans and are then solely influenced by the rural forest ecosystem. Habitats will be directly affected without dark forest thinning and litter collections. Hence, abandonment may disturb natural regeneration and this could influence rural landscape biodiversity.

The relationship between biodiversity and spatial patterns in Maeul landscapes is considered to develop sustainable rural-landscape management practices. Moderate human impacts may support rural-landscape biodiversity when spatial patterns are carefully controlled (Solon 1995, Hong 2001, Croissant 2004). Furthermore, land-use strategies regarding spatial patterns should account for their influence on ecosystem function (Reenberg and Baudry 1999, Bogaert and Hong 2004).

Finally, the findings of this study provide important information for sustainable landscape planning and management of the Maeul landscape as Korean traditional rural landscape in the future. Furthermore, it is concluded that traditional human activities, particularly in rural secondary forests, which control forest succession and biodiversity, will be required to maintain the heterogeneity of vegetation communities and spatial patterns over time. Moreover, sustainable rural-landscape planning and management require multi-disciplinary approaches given the inherent complexities of rural landscapes.

\section{ACKNOWLEDGMENTS}

We are grateful to Prof. Nobukazu Nakagoshi of Hiroshima University, Japan, for his invaluable suggestions. This research was supported partly by a National Research Foundation of Korea Grant funded by the Korean Government (MEST) (NRF-2009-361-A00007).

\section{LITERATURE CITED}

Baker WL. 1995. Long-term response of disturbance landscapes to human intervention and global change. Landsc Ecol 10: 143-159.

Beon MS, Bartsch N. 2003. Early seedling growth of pine (Pinus densiflora) and oaks (Quercus serrata, Q. mongolica, Q. variabilis) in response to light intensity and soil moisture. Plant Ecol 167: 97-105.

Berkes F, Colding J, Folke C. 2000. Rediscovery of traditional ecological knowledge as adaptive management. Ecol Appl 10: 1251-1262.

Bogaert J, Hong SK. 2004. Landscape ecology: monitoring landscape dynamics using spatial pattern metrics. In: Ecological Issues in a Changing World: Status, Response and Strategy (Hong SK, Lee JA, Ihm BS, Farina A, Son Y, Kim ES, Choe JC, eds). Kluwer, Dordrecht, pp 109-131.

Braun-Blanquet J. 1964. Pflanzensoziologie, Grundzüge der Vegetationskunde. 3 Aufl. Springer-Verlag, Wien.

Burel F, Baudry J. 1995. Species biodiversity in changing agricultural landscapes: a case study in the Pays d'Auge, France. Agric Ecosyst Environ 55: 193-200.

Choung HL, Hong SK. 2006. Distribution patterns, floristic differentiation and succession of Pinus densiflora forest in South Korea: a perspective at nation-wide scale. Phytocoenologia 36: 213-229.

Croissant C. 2004. Landscape patterns and parcel boundaries: an analysis of composition and configuration of land use and land cover in south-central Indiana. Agric Ecosyst Environ 101: 219-232.

Forman RTT. 1995. Land Mosaics: The Ecology of Landscapes and Regions. Cambridge University Press, Cambridge.

Fukamachi K, Oku H, Nakashizuka T. 2001. The change of a Satoyama landscape and its causality in Kamiseya, Kyoto Prefecture, Japan between 1907 and 1995. Landsc Ecol 16: 703-717. 
Golley FB, Bellot J. 1999. Planning as a way of achieving sustainable development. In: Rural Planning from an Environmental Systems Perspective (Golley FB, Bellot J, eds). Springer, New York, NY, pp 3-17.

Hietala-Koivu R. 1999. Agricultural landscape change: a case study in Yläne, southwest Finland. Landsc Urban Plan 46: 103-108.

Hong SK. 1998. Changes landscape patterns and vegetation process in the Far-Eastern cultural landscapes: human activity on pine-dominated secondary vegetations in Korea and Japan. Phytocoenologia 28: 45-66.

Hong SK. 2001. Factors affecting landscape changes in central Korea: cultural disturbance on the forested landscape systems. In: Landscape Ecology Applied in Land Evaluation, Development and Conservation: Some Worldwide Selected Examples (van der Zee D, Zonneveld IS, eds). ITC Publisher, Enschede, pp 131147.

Hong SK. 2007. Linking man and nature landscape systems: landscaping blue-green network. In: Landscape Ecological Applications in Man-Influenced Areas: Linking Man and Nature Systems (Hong SK, Nakagoshi N, Fu B, Morimoto Y, eds). Springer, Tokyo, pp 505-524.

Hong SK, Nakagoshi N, Kamada M. 1995. Human impacts on pine-dominated vegetation in rural landscapes in Korea and western Japan. Vegetatio 116: 161-172.

Jeanneret Ph, Schüpbach B, Luka H. 2003. Quantifying the impact of landscape and habitat features on biodiversity in cultivated landscapes. Agric Ecosyst Environ 98: 311-320.

Jongman RHG, ter Braak CJF, van Tongeren OFR. 1995. Data Analysis in Community and Landscape Ecology. Cambridge University Press, Cambridge.

Kamada M, Nakagoshi N. 1993. Pine forest structure in a human-dominated landscape system in Korea. Ecol Res 8: 35-46.

Kamada M, Nakagoshi N. 1996. Landscape structure and the disturbance regime at three rural regions in Hiroshima Prefecture, Japan. Landsc Ecol 11: 15-25.

Kim JE, Hong SK, Nakagoshi N. 2002. Landscape ecology on vegetation types and land use systems of agro-forested regions in Korea. Hikobia 13: 693-703.

Kim JE, Hong SK, Nakagoshi N. 2006. Changes in patch mosaics and vegetation structure of rural forested landscapes under shifting human impacts in South Korea. Landsc Ecol Eng 2: 177-195.

Kim JE, Hong SK, Nakagoshi N. 2007. International trends of rural landscape researches for land management and policies. In: Landscape Ecological Applications in Man-Influenced Areas: Linking Man and Nature System
(Hong SK, Nakagoshi N, Fu B, Morimoto Y, eds). Springer, Tokyo, pp 489-504.

Lee D. 2004. Ecological Knowledge Embedded in Traditional Korean Landscape. Seoul National University Press, Seoul. (in Korean)

Lee YN. 1996. Flora of Korea. Kyo-Hak Publishing Co., Seoul. (in Korean)

Lim HB, Cho JK. 2004. A comparative study on rural development of Korea and EU. J Korean Soc Rural Plan 10: 25-34. (in Korean with English abstract)

McGarigal K, Marks BJ.1995. FRAGSTATS: Spatial Pattern Analysis Program for Quantifying Landscape Structure. General Technical Report, PNW-GTR-351. U.S. Department of Agriculture, Forest Service, Pacific Northwest Research Station, Portland, OR.

Morisita M. 1959. Measuring of interspecific association and similarity between communities. Mem Fac Sci Kyushu Univ Ser E (Biol) 3: 65-80.

Moser D, Zechmeister HG, Plutzar C, Sauberer N, Wrbka T, Grabherr G. 2002. Landscape patch shape complexity as an effective measure for plant species richness in rural landscapes. Landsc Ecol 17: 657-669.

Nakagoshi N, Hong SK. 2001. Vegetation and landscape ecology of East Asian 'Satoyama'. Glob Environ Res 5: 171-181.

Nakagoshi N, Kamada M, Hong S-K. 1992. Map of actual vegetation of Miwa-cho, Hiroshima Prefecture. Bull Biol Soc Hiroshima Univ 58: 3-6 (include map).

Oreszczyn S. 2000. A systems approach to the research of people's relationships with English hedgerows. Landsc Urban Plan 50: 107-117.

Pinto-Correia T. 2000. Future development in Portuguese rural areas: how to manage agriculture support for landscape conservation? Landsc Urban Plan 50: 95-106.

Reenberg A, Baudry J. 1999. Land-use and landscape changes: the challenge of comparative analysis of rural areas in Europe. In: Land-Use Changes and Their Environmental Impact in Rural Areas in Europe (Krönert R, Baudry IRB, Reenberg A, eds). UNESCO and Parthenon Publishing, Paris, pp 23-41.

Saïd S. 2001. Floristic and life form diversity in post-pasture successions on a Mediterranean island (Corsica). Plant Ecol 162: 67-76.

Shin JH. 2002. Ecosystem geography of Korea. In: Ecology of Korea (Lee D, Jin V, Choe JC, Son Y, Yoo S, Lee HY, Hong SK, Ihm BS, eds). Bumwoo Publishing Co., Seoul, pp 19-46.

Solon J. 1995. Anthropogenic disturbance and vegetation diversity in agricultural landscapes. Landsc Urban Plan 31: 171-180. 
Takeuchi K. 2010. Rebuilding the relationship between people and nature: the Satoyama Initiative. Ecol Res 25: 891-897.

Turner MG, Gardner RH, O’Neill RV. 2001. Landscape Ecology in Theory and Practice. Springer-Verlag, New York, NY.

Turner MG, Wear DN, Flamm RO. 1996. Land ownership and land-cover change in the southern Appalachian highlands and the Olympic peninsula. Ecol Appl 6: 1150-1172.

van Lier HN. 1998. The role of land use planning in sustainable rural systems. Landsc Urban Plan 41: 83-91.
Walker BH, Langridge JL. 2002. Measuring functional diversity in plant communities with mixed life forms: a problem of hard and soft attributes. Ecosystems 5: 529-538.

Washitani I. 2003. Satoyama landscapes and conservation ecology. In: Satoyama: The Traditional Rural Landscape of Japan (Takeuchi K, Brown RD, Washitani I, Tsunekawa A, Yokohari M, eds). Springer-Verlag, Tokyo, pp 1623.

Woodhouse SP, Good JEG, Lovett AA, Fuller RJ, Dolman PM. 2005. Effects of land-use and agricultural management on birds of marginal farmland: a case study in the Llŷn peninsula, Wales. Agric Ecosyst Environ 107: 331-340. 